\title{
Problem Based Learning Models With Student Worksheets: Effect on Higher Order Thinking Skills in Digestive System Concept
}

\author{
Anggun Wicaktini ${ }^{1}$, Nengsih Juanengsih ${ }^{2}$, Meiry Fadilah Noor ${ }^{3}$ \\ \{anggun.wicaktini@gmail.com $^{1}$, nengsih.juanengsih@uinjkt.ac.id ${ }^{2}, \underline{\text { meiryfadilah@uinjkt.ac.id }}{ }^{3}$ \} \\ ${ }^{1,2,3}$ UIN Syarif Hidayatullah Jakarta, Indonesia
}

\begin{abstract}
Problem-based learning is used to develop high order thinking skills, in problem-oriented situations, including how to learn. Problem-based learning is a learning model dependent on the rule that issues can be utilized as a beginning stage to get or coordinate new information. This study aimed at determining the effect of problem based learning models with student worksheets on students' high order thinking skills on the digestive system concept. In this study problem solving steps were developed in a student worksheets. This student worksheets contains questions that can develop students' thinking skills, from low-order thinking to high-order thinking. High order thinking skills measured in this study is limited to Bloom's taxonomy of cognitive revisions analysing (C4), evaluating (C5) and creating (C6) The research method used was quasi experiment with the design of the non-equivalent controlled group design. The subjects in this study were students of SMAN 8 Tangerang Selatan Academic Year 2015/2016. The sampling technique in this study was by simple random sampling. The sample in this study consisted of two classes: XI IPA 1 as the experimental group and XI IPA 5 as the controlled group, each had 32 students. The instrument was in the form of subjective tests using 13 items, each of 5 questions to analyse (C4), 5 questions to evaluate (C5) and 3 questions to create (C6). The data of the test results were analysed by using the t-test, at a significance level of 0.05 . Based on the result, it has found that problem based learning models with student worksheets had a significant effect on students' high order thinking skills on the digestive system concept. This study aims to identify the impact of problembased learning (PBL) to students' higher-order thinking skill. The notion of higher-order thinking is designed based on Bloom's taxonomy, and implemented into students' worksheet particularly on the topic of digestive system concept. 64 students from two science classes at a secondary high school in South Tangerang participated in this experimental study. Findings of the study revealed that problem-based learning models with student worksheets had a significant effect on students' high order thinking skills on the digestive system concept.
\end{abstract}

Keywords. Problem-based learning, Student worksheets, high order thinking skills.

\section{Introduction}

Education is a cognizant and arranged exertion to make a learning climate and learning process so student can effectively build up their potencies to have religious profound power, restraint, character, insight, respectable character, and abilities required by them, society, country and state [1]. Education is one aspect of life that plays an important role. A country 
can achieve progress if education is in good quality. Education that has good quality must be supported by teacher's ability to carry out learning and teaching activities in the classroom. Teachers must master various active and interactive learning methods so that teaching and learning activities become more interesting and meaningful.

In reality, education in Indonesia today still has low quality. A number of member countries of the ASEAN Economic Community (MEA) are making optimal preparation efforts by improving the quality of education. Indonesian Human Resources competency is still very low. In terms of the quality of education, Indonesia is still ranked lowest in the world. One of the contributing factors is the low quality of teachers or teaching staff in Indonesia. Minister of Education and Culture Muhadjir Effendy emphasized that the thing that most determines the quality of education is the teacher [2].

The results of the Trends of the International Mathematics and Science Study (TIMSS) in 2007 ranked Indonesia as the lowest in Science and Mathematics. In fact, Indonesian students have not been able to answer the questions well. This is because Indonesian students are not accustomed to working on questions that require high-order thinking skills. The unfamiliarity of students in working on questions that demand high-order thinking skills is suspected because the teacher is not used to giving questions that require high-order thinking skills [3].

Learning thinking skills in Indonesia have several obstacles. One of them is the overly dominant role of the teacher in the school as a disseminator of knowledge or a source of knowledge, so students are only considered as blank papers that will be filled with knowledge by the teacher. Another obstacle is that the student achievement assessment system is based more on a low level cognitive ability test. The form of assessment conducted on student performance still tends to follow the old pattern, which is the multiple choice model that requires students to memorize [4].

The challenge faced by teachers now is how to help students to practice to be independent learners in learning. One way that teachers can do to overcome the obstacles and the challenges during the learning process is the use of media or learning aids that can facilitate students in the learning process. One of the media or tools that can be used in the learning process is student worksheets. Student worksheet can improve the learning accomplishment and make student logically powerful and compelling in learning[5]. Also student worksheet can improve the knowledge of student[6]. However, student worksheets used by teachers is usually taken from the publisher. Some schools also use student worksheets that are designed and developed by teachers in accordance with the conditions and situations of learning activities that will be faced.

Student worksheets purchased by publishers are actually books summarized subject matter accompanied by a collection of questions, such as multiple 'choice questions, essay questions and description questions. Those questions can be answered by students by looking at the material in student worksheets. These type of worksheets make students not independent and do not train students in applying their intelligence [7].

The analysis of the quality of the contents of student worksheets discovered that there were various ideas that could conceivably prompt student misconceptions, the entire Biology student worksheets both in the Middle School (between 40-88\%) and High School (20-55\%). The relevance of those contents of student worksheet with KTSP ranges from $59-100 \%$ (Middle School) and 50 - 100\% (High School). It was revealed that both Middle and High School student worksheets could potentially not be of the appropriate age level, besides there were also many spelling mistakes, that lead to easy questions which are dominated by factual and informative questions on cognitive levels $\mathrm{C} 1$ and $\mathrm{C} 2$ [8]. 
Student worksheets are still dominated by factual questions and informative questions, namely asking what is observed and the relation of one object to another object, and answers to questions directly obtained by students from text or material summaries. That certainly does not activate students thinking skills. It can be said that the answers can be seen in the material summary in the student worksheets, and that does not activate the students thinking skills. Meanwhile, students should be accustomed to questions that can activate students thinking skills. In this case the question must be in the form of information-gathering questions or problem solving.

The questions contained in the Biology student worksheet tend to be dominated by questions with cognitive levels C1 (remembering) and C2 (understanding). This shows that the questions contained in the Biology student worksheet do not support the growth of high-order thinking skills [8]. A teacher in the class has responsibility in terms of improving students' thinking skills from thinking about real things to thinking about abstract things. Through problem-based learning students are taught to think gradually from identifying problems to being able to solve problems and it is a way to train students in High Order Thinking Skills (HOTS). HOTS is the skills to associate, control, and change the current learning and experience to imaginative deduction in settling on choices and taking care of issues in new circumstances [9].

One of the issues looked in the realm of training today is the frail learning process in schools, where student are less urged to create thinking skills. Media can be a necessary piece of learning exercises with the goal that its position can't be isolated and impacts the course of learning process. Learning is a procedure of correspondence among teacher and students, some teachers use learning resources in the form of Student Worksheet [10].

Problem based learning (PBL) is an instructional model that has been used accomplishment totally for over 30 years and continues getting affirmation in different controls. It is an instructional (and curricular) understudy centered that empowers student to direct research, facilitate speculation and practice, and apply data and capacities to develop an attainable response for a described issue [11]. Students in problem based learning gathering gave off an impression of being progressively capable in the utilization and association of significant data, in building information and pushing toward better ends [12].

Problem-based learning models are required to do problem solving presented by digging as much information as possible, then analysed and sought solutions to existing problems. The solution to these problems does not absolutely have one correct answer, meaning students are also required to learn creatively. Students are required to be knowledgeable individuals and able to see the relationship between learning and aspects in the environment. The concept will be tested through student worksheet based on Problem Based Learning [4].

PBL with the high-order thinking skills can be applied by the concept of the digestive system. There are some interesting problems to be solved by students regarding problems related to the human digestive system. The importance of knowing the digestive system has a positive impact on the daily lives of students. What can be done in developing students' higher-order thinking skills is with the help of media in the form of student worksheets.

Student worksheets can be used as support in classroom learning activities which are ways to achieve learning goals. Students worksheets can train students to develop thinking skills from thinking concrete things to thinking abstract things. Referring to the basic competencies in the cognitive and psychomotor aspects require students to be able to develop students' skills in analysing conceptual knowledge and to present the results of their analysis in the form of presentations. These basic competencies direct students to develop high-order 
thinking skills such as at the level of the cognitive process of analysing, evaluating, and creating.

Regarding these problems, the research questions are: Is there an Effect of Problem Based Learning Models With Student Worksheets on High Order Thinking Skills in Digestive Systems Concept ? My hypothesis is: There is a significant positive effect of Problem Based Learning Models With Student Worksheets to High Order Thinking Skills in Digestive Systems Concept.

\section{Method}

The research method used was the quasi experimental design. The design of this study used the nonequivalent controlled group design. This study used two class groups, namely experimental and controlled groups. In the experimental group, the learning was given by using the PBL model with Student worksheets based on PBL while the controlled group used a scientific approach with usual worksheets. The number of lessons for each group was 3 meetings. The stages of student activity on student worksheets for both groups can be seen in Table 1.

The subjects in this study were students of a public school in South Tangerang Year 2015/2016. The sample was class XI IPA 1 which then was called the experimental group and class XI IPA 5 which then was called the controlled group, each group of 32 students. This study measured high-order thinking skills in both groups.

The research instrument used was a subjective test in the form of a description question as many as 13 items. The description questions were arranged based on the components of the High Order Thinking Skills to be achieved, namely the question of the level of Bloom's taxonomy. Bloom's taxonomy contains six categories of cognitive skills going from lowerorder skills that require less cognitive processing to higher-order skills that require further learning and a more noteworthy level of cognitive processing [13]. The categories included in the higher-order skills are analyzing (C4), evaluating (C5), and creating (C6). Each question has been tested for validity and reliability.

Table 1. The stages of student activity on student worksheets

\begin{tabular}{|c|c|c|}
\hline Stage & Experiment Group & Control Group \\
\hline \multirow[t]{2}{*}{1} & Found a problem & Observing \\
\hline & $\begin{array}{l}\text { Write down the problem you found based on the } \\
\text { fact analysis of the discourse above! }\end{array}$ & $\begin{array}{l}\text { Observe the following picture and complete the } \\
\text { names of the parts! }\end{array}$ \\
\hline \multirow[t]{2}{*}{2} & Define the problem & Asking \\
\hline & $\begin{array}{l}\text { Define clearly with your friends the problem of } \\
\text { fact } 1 \text {, fact } 2 \text {, fact } 3 \text { in the discourse! }\end{array}$ & $\begin{array}{l}\text { Observe the picture, and make at least } 3 \\
\text { questions from the picture! }\end{array}$ \\
\hline \multirow[t]{3}{*}{3} & Gathering facts & Exploring \\
\hline & $\begin{array}{l}\text { Look for some fact literature from what is listed } \\
\text { in the available sources and other sources based } \\
\text { on }\end{array}$ & $\begin{array}{l}\text { Answer the question that you made in the } \\
\text { column below! }\end{array}$ \\
\hline & $\begin{array}{l}\text { a. what information do you know } \\
\text { b. what information you need } \\
\text { c. what do you do with the information available }\end{array}$ & \\
\hline \multirow[t]{2}{*}{4} & Make a hypothesis & Associating \\
\hline & $\begin{array}{l}\text { Make a provisional guess or a provisional answer } \\
\text { to the problem you identified! }\end{array}$ & $\begin{array}{l}\text { Is there a relationship between the questions } \\
\text { you make and the answers you have been }\end{array}$ \\
\hline
\end{tabular}




\begin{tabular}{|c|c|c|}
\hline Stage & Experiment Group & Control Group \\
\hline \multirow{3}{*}{5} & & $\begin{array}{l}\text { looking for with the conditions in real daily } \\
\text { life. Make conclusions in your own words } \\
\text { about the relationship and what actions we can } \\
\text { take in overcoming conditions of negligence in } \\
\text { the digestive system! }\end{array}$ \\
\hline & Carry out an investigation & Communicating \\
\hline & $\begin{array}{l}\text { Investigate the data / information you get from } \\
\text { the literature regarding the problem you identified } \\
\text { and write the results of your investigation to } \\
\text { support } \\
\text { the hypothesis you gave! }\end{array}$ & $\begin{array}{l}\text { Present the results of your discussion in front } \\
\text { of the class and record responses or comments } \\
\text { from other groups! }\end{array}$ \\
\hline \multirow[t]{2}{*}{6} & Perfecting the problem & - \\
\hline & $\begin{array}{l}\text { Relate the problems that exist in the discourse } \\
\text { with the data / information you get from the } \\
\text { literature to improve the problem! }\end{array}$ & \\
\hline 7 & $\begin{array}{l}\text { Make conclusions together } \\
\text { make alternative conclusions based on problem } \\
\text { solving based on information, facts and data that } \\
\text { you have found, associate with other problems! }\end{array}$ & - \\
\hline \multirow[t]{2}{*}{8} & Solution to solve problems & - \\
\hline & $\begin{array}{l}\text { Test the solution (solution) you gave in number } 7 \\
\text { by including your opinion and also data / } \\
\text { information from various sources to support the } \\
\text { solution } \\
\text { that you give! }\end{array}$ & \\
\hline
\end{tabular}

During the research process, the researcher conducted two tests, namely the pre-test (initial test) to decide the students' underlying capacity before being given treatment and posttest (final test) to find out the results of the treatment that has been given. The questions utilized at the pre-test and post-test were similar questions, so there was no influence on the quality of difference. Processing and analysing data were used by statistical tests. The steps in using statistical tests are as follows: Normality Test, homogeneity test, and hypothesis test by using SPSS 23 software.

\section{Result and Discussion}

The results of the study explained the general description of the data that has been obtained. The data described were the data from the pretest, posttest, Student worksheets, analysis prerequisite test, and hypothesis testing from the experimental and controlled groups.

Table 2. Data of Pre-test and Post-test for High Order Thinking Skills

\begin{tabular}{lllll}
\hline \multirow{2}{*}{ Data } & \multicolumn{2}{c}{ Experiment } & \multicolumn{2}{c}{ Control } \\
\cline { 2 - 5 } & Pre-test & Post-test & Pre-test & Post-test \\
\hline $\mathrm{N}$ & 32 & 32 & 32 & 32 \\
Top Value (Max) & 54.90 & 90.20 & 54.90 & 86.27 \\
Lowest Value (Min) & 21.57 & 47.05 & 23.53 & 43.13 \\
Average & 41.61 & 74.02 & 38.97 & 66.79
\end{tabular}




\begin{tabular}{lllll} 
Category & Low & Good & Low & Medium \\
Median & 42.16 & 76.47 & 38.24 & 64.71 \\
Mode & 29.41 & 88.24 & 45.10 & 80.39 \\
Standard Deviation (SD) & 9.99 & 12.63 & 7.52 & 12.18 \\
\hline
\end{tabular}

Table 3. Percentage of high level thinking skills

\begin{tabular}{lcccc}
\hline \multirow{2}{*}{ HOTS level } & \multicolumn{2}{c}{ Experiment } & \multicolumn{2}{c}{ Control } \\
\cline { 2 - 5 } & Pre-test & Post-test & Pre-test & Post-test \\
\hline C4 & 38.92 & 77.47 & 32.24 & 63.65 \\
C5 & 39.22 & 68.91 & 36.41 & 65.31 \\
C6 & 49.74 & 77.08 & 53.91 & 74.22 \\
Average & 42.65 & 74.49 & 40.85 & 67.73 \\
\hline
\end{tabular}

The average in Table 2 illustrates that the two groups do not yet know the concepts to be taught so that the initial ability of students in high-level thinking skills is still relatively low. On Table 3, the acquisition of the posttest results of the two groups, the C6 level was the one that had the highest results compared to the other levels while the lowest level in the two groups was the C5 level. Based on the Table 3, it can be seen that the increase in the results of each level was good so that the two groups after being given learning can answer the question of Higher Order Thinking Skills. Although both groups experienced an increase after being given learning, the experimental group had a much better improvement compared to the controlled groups so that student worksheet based on PBL was felt to have more influence in improving students' Higher Order Thinking Skills. The results of student worksheets based on PBL in experiment group can be seen in Table 4.

Table 4. Average Value of Student Worksheets in experiment group, on class meetings 1, 2 and 3

\begin{tabular}{lllll}
\hline HOTS level & Student worksheet 1 & Student worksheet 2 & Student worksheet 3 & Average \\
\hline C4 & 62.11 & 66.02 & 66.02 & 64.71 \\
C5 & 75.00 & 69.53 & 71.48 & 72.00 \\
C6 & 65.04 & 66.41 & 71.88 & 67.77 \\
Average & 67.38 & 67.32 & 69.79 & 68.18 \\
\hline
\end{tabular}

Data of the Table 4 showed, the average value of Student worksheets worked by the students during the learning process in the first, second and third class meetings included in the sufficient category. Based on the calculation, the differences in each meeting were obtained. But, for student worksheets at each grade point average class meetings only experienced a slight increase in value. The highest average results of worksheets 1, 2 and 3 were at the C5 level compared to the levels of C4 and C6, so that it can be interpreted that in dominant terms the students can work on the C5 level problem contained in the student worksheet each meeting in a good category. The experimental group during the learning process was assisted by Student Worksheets based on PBL in which there were indicators of High-Order Thinking Skills while the controlled group was only given a student worksheet according to the scientific approach in which there were no indicators of High-Order Thinking Skills. High-Order Thinking Skills from Post-test data calculation results for each sub-concept are in Table 5. Table 5 shows that High-Order Thinking Skills in food sub-concepts has the highest percentage compared to percentages in other sub-concepts.

Tabel 5. High-Order Thinking Skills post- test data on each sub concept 


\begin{tabular}{lcccc}
\hline \multicolumn{1}{c}{ Sub-concept } & Eksperiment group & Category & Control Group & Category \\
\hline 1. Human Digestive System & 73,91 & Good & 66,58 & Sufficient \\
2. Food Substances & 74,35 & Good & 69,40 & Sufficient \\
3. Ruminant digestive system & 72,66 & Good & 52,34 & Less \\
Average & 73,64 & Good & 62,77 & Sufficient \\
\hline
\end{tabular}

The results of the normality test on the pretest and posttest data of the two groups obtained results that, the data were normally distributed. The homogeneity test results, the pre-test and the post-test data of the two groups were homogeneous.

Table 6. Pre-test and Post-test Hypothesis Testing

\begin{tabular}{llllll}
\hline Data & Experiment & Control & $\mathrm{t}_{\text {count }}$ & table & Conclusion \\
\hline Pre-test & 41.61 & 38.97 & 1.195 & 1.998 & $\mathrm{H}_{0}$ accepted \\
Post-test & 74.02 & 66.79 & 2.331 & 1.998 & $\mathrm{H}_{0}$ rejected \\
\hline
\end{tabular}

Table 6 showed that the pre-test or initial ability of the students in the two groups had no difference, so the two groups were worthy of being used as samples because they had the same initial abilities. Table 6 also showed that the post-test of the two groups was significantly different, which means that there was a treatment effect on improving the students' high-order thinking skills.

The experimental group was treated using student worksheets based on PBL which contained indicators of High Order Thinking Skills. Obtaining the average value of the student worksheets for three class meetings belongs to a sufficient category, this is because the students were not yet used to using Student worksheets based on PBL that also measure the aspects of high-order thinking skills. However, the acquisition of average scores experienced a slight increase in each meeting, this shows that the students are increasingly getting used to working on student worksheets based on PBL. In student worksheets based on PBL indicators of students' high-order thinking skills can be explored through the stages in PBL. During the process of working on student worksheets, the students must be able to determine the problems identified from the discourse presented. Then the students made hypotheses and determine their own solutions chosen in solving the problems identified in the discourse. Student worksheets based on PBL contain stages of PBL oriented also on High-Order Thinking Skills indicators according to Bloom's taxonomy, C4, C5, and C6.

C4 level value data (analysing) contain several questions in the student worksheet including determining the subject matter, formulating the problem, comparing the hypothesis with the information that has been sought. These questions can help students develop analytical skills. Problem based learning can develop critical and analytical thinking skills and and open student to exercise to tackle issues, in actuality [14].

C5 level value data (evaluating) contain several questions including finding solutions to problems based on the information sought and examining selected solutions with hypotheses and facts found. These questions can help students develop evaluation skills,. learning that involves problem analysis, hypothesis formulation, variable manipulation, and designing, as well as carrying out investigations, making predictions of interpreting the results of investigations which can develop the ability of analytical and logical thinking in students [14].

C6 level value data (creating) contain several questions in the student worksheet including seeking information in various sources, making hypotheses, and concluding selected solutions. These questions can help students develop skills in creating or generating ideas and designing problems. Problem-based learning is a learning model with students learning approaches to authentic problems so students can 
develop their own knowledge, develop high-order thinking skills and inquiry, empower students and increase self-confidence [15].

In this study, the researchers used indicators that were in accordance with the stages of the PBL model. The stages in PBL can help and train the students' thinking skills so the students are more active, dare to express opinions and able to produce many ideas as an alternative problem solving. This is in line with at research conducted by Afcariono, that states that the types of answers $\mathrm{C} 1$ to $\mathrm{C} 3$ have decreased and increased in the types of answers C4, C5 and C6. These results indicate that the mindset during the learning process increases from low-order thinking to high-order thinking [16]. This increase can not be separated from the application of problem-based learning in the learning process.

The results of this study are in line with at research conducted by Noma et al., that the research target has been achieved because each aspect has increased. The students are getting used to using highorder thinking skills during the learning process. It was proven by students who began smoothly in formulating problems, arranging temporary answers, planning investigative activities, and making conclusions from learning material that had been studied [17].

Problem based learning is a viable way to deal with train high-order thinking skills. This learning enables student to process data that has been shaped in their psyches and accumulate their own insight about the social world and its environment. This knowledge is suitable for developing basic and complex abilities [18]. Further, with the utilization of PBL student could build up the capacity of thinking in speculation in light of the fact that PBL puts accentuation on learning with an issue as premise [19]. The use of the PBL model trains students to have high-order thinking skills. In addition, assisted by student worksheets based on PBL students can practice to formulate problems, do hypotheses, conduct investigations, draw conclusions and make products/work that all require students with high-order thinking skills [20].

\section{Conclusion}

The findings of this study are that there was an influence of problem based learning models with student worksheets toward students' high order thinking skills in the digestive system concept. This showed that there were differences in the results of the students' high order thinking skills between the experimental group and the controlled group where the experimental group has a better average value of 74.02 compared to the controlled group with an average value of 66.79. Further, it is advised for teachers to train the student with high order thinking skills.

\section{References}

[1] Undang-undang Republik Indonesia, "Undang-undang Republik Indonesia Nomor 20 Tahun 2003 Tentang Sistem Pendidikan Nasional.” pp. 1-33, 2003.

[2] Y. Debora, "Mendikbud: Kualitas Pendidikan Ditentukan Guru," tirto.id, 2016.

[3] Y. Herlanti and N. Nopithalia, "Meneropong kualitas soal tes buatan guru biologi MTs Negeri se-Jakarta Selatan,” 2007.

[4] E. Sastrawati, M. Rusdi, and Syamsurizal, "Problem-Based Learning, Strategi Metakognisi, dan Keterampilan Berpikir Tingkat Tinggi Siswa," Tekno-Pedagogi, vol. 1, no. 2, pp. 1-14, 2011.

[5] C. L. B. Trewet and N. Fjortoft, "Evaluation of the impact of a continuing professional development worksheet on sustained learning and implementing change after a continuing pharmacy education activity," Res. Soc. Adm. Pharm., vol. 9, no. 2, pp. 
215-221, 2013.

[6] W. Sri Utami, Sumarmi, I. N. Ruja, and S. Utaya, "The Effectiveness of Geography Student Worksheet to Develop Learning Experiences for High School Students," J. Educ. Learn., vol. 5, no. 3, pp. 315-321, 2016.

[7] A. B. Tanjung, R. Lestari, and E. Brahmana, "Pengembangan Lembar Kerja Siswa (LKS) Berbasis Multiple Intelligences Untuk Kelas VIII SMP Materi Pertumbuhan dan Perkembangan," J. Pendidik., vol. 3, no. 1, pp. 1-6, 2017.

[8] E. Chandra et al., "Kualitas Isi LKS Biologi yang digunakan di SMP dan SMA di Wilayah Cirebon," J. Semin. Nas. dan Rapat Tah., pp. 101-108, 2014.

[9] R. R. Sihaloho, S. Sahyar, and E. M. Ginting, "The Effect of Problem Based Learning (PBL) Model toward Student's Creative Thinking and Problem Solving Ability in Senior High School," IOSR J. Res. Method Educ., vol. 07, no. 04, pp. 11-18, 2017.

[10] S. Juariyah, H. Deswita, and Arcat, "Pengembangan lembar kerja siswa matematika berbasis masalah untuk kelas VIII SMP Materi Kubus dan Balok," J. Ilm. Mhs. Prodi Mat. UPP, vol. 2, no. 1, pp. 1-8, 2016.

[11] J. R. Savery, "Overview of PBL: Definitions and distinctions," Interdiscip. J. Probl. Learn., vol. 1, no. 1, pp. 9-20, 2006.

[12] S. Sungur, C. Tekkaya, and Ö. Geban, "Improving achievement through problembased learning," J. Biol. Educ., vol. 40, no. 4, pp. 155-160, 2006.

[13] N. E. Adams, "Bloom's taxonomy of cognitive learning objectives," J. Med. Libr. Assoc., vol. 103, no. 3, pp. 152-153, 2015.

[14] I. B. P. Arnyana, "Pengaruh Penerapan Model PBL dipandu Strategi Koopertaif Terhadap Kecakapan Berpikir Kritis Siswa SMA Pada Mata Pelajaran Biologi,” J. Pendidik. dan Pengajaran IKIP Negeri Singaraja, vol. 4, pp. 1-15, 2005.

[15] A. A. Sanjaya, "Pembelajaran Berbasis Masalah, Apa Karakteristik dan Implikasi?," in Seminar Nasional Matematika dan Pendidikan Matematika, 2015, pp. 109-114.

[16] M. Afcariono, "Penerapan Pembelajaran Berbasis Masalah untuk Meningkatkan Kemampuan Berpikir Siswa pada Mata Pelajaran Biologi,” J. Pendidik. Inov., vol. 3, no. Nomor 2, pp. 65-68, 2008.

[17] L. D. Noma, B. A. Prayitno, and Suwarno, "PBL Untuk Meningkatkan Kemampuan Berpikir Tingkat Tinggi Siswa Kelas X SMA,” Bioedukasi, vol. 9, no. 2, pp. 62-66, 2016.

[18] Trianto, Model-Model Pembelajaran Inovatif Berorientasi Konstruktivistik, Konsep, Landasan Teori-Praktis dan Implementasinya. Jakarta: Prestasi Pustaka Publikasi, 2007.

[19] Mundilarto and H. Ismoyo, "Effect of problem-based learning on improvement physics achievement and critical thinking of senior high school student," J. Balt. Sci. Educ., vol. 16, no. 5, pp. 761-779, 2017.

[20] M. Zaini, U. I. Sewenda, and A. Ajizah, "Hasil Belajar dan Keterampilan Berpikir Tingkat Tinggi Siswa SMA Pada Pembelajaran Biologi Menggunakan Model Pembelajaran Berdasarkan Masalah," in Prosiding Seminar Nasional IPA VI Unnes, 2015, pp. 1-8. 